\title{
The Comparison of Objective Evaluation and Subjective Assessment for Hearing and Vision in the Elderly
}

\author{
Ki-Sun Kim \\ Department of Technical Education, Sehan University, Yeongam, Korea \\ 노인의 청력과 시력에 대한 객관적 검사와 주관적 평가 비교 \\ 김 기 선 \\ 세한대학교 기술교육과
}

\begin{abstract}
Purpose: The weakness of functions with hearing and vision sensory peripheral system induced cognitive decrease and negative effects in everyday life, and quality of life in the elderly also. Dual sensory loss, hearing loss and vision impairment, was more affected than just one sensory problem. However, the full extent of hearing and vision impairments is not well known. Therefore the aims of the present study were to determine the prevalence of hearing and vision impairments. Methods: This study was showed the prevalence of hearing and vision impairment by age, gender, hearing loss degree, and vision impairment degree in the Jeollanam-do older people. Results: The difficulties of hearing and vision experienced in everyday life by questionnaire were investigated and compared the results obtained objective evaluation. In this study, the elderly people about $66 \%$ were had dual sensory loss and almost people were experienced difficulties through everyday life. The most proportion of participants could not have activity limitation, but 96\% felt participation restrictions. The most commonly reported difficulties were participation restrictions in visual impairments. Conclusion: The objective evaluations and subjective assessments for hearing and vision need to provide appropriate rehabilitation. Also this research data were prepared for welfare for the elderly.
\end{abstract}

Key Words: Hearing loss, Vision impairment, Dual sensory loss, Objective evaluation, Subjective questionnaire.

Received: December 7, 2015 / Revised: December 28, 2015 / Accepted: January 12, 2016

Correspondence: Ki-Sun Kim, Department of Technical Education, Sehan University, 1113 Noksaek-ro, Samho-eup, Yeongam 58447, Korea Tel: +82-61-469-1303 / Fax: +82-61-469-1353 / E-mail: kskim@sehan.ac.kr

\section{INTRODUCTION}

산업화·세계화·복지화를 통하여 세계의 인구는 증가하고 있다. 특히 의료기술의 향상, 복지제도의 다양화, 과학기술의 발달로 인간의 수명은 날로 증가하고 있으나 무한 경쟁 속에서 일부 국가는 출생률이 낮은 관계로 고령화는 가속 추세에 있 다. 그중 특히 우리나라의 고령화 속도는 세계에서도 유래가 없 을 정도로 빠르게 진행되고 있다. 우리나라의 65세 이상 노인 인구는 2010년 11\%에서 2018년에는 14.3\%로 고령화 사회로 접 어들게 될 것이며, 2026년에는 $20.8 \%$ 로 예측되어 초고령화 사 회가 될 전망이다. 또한 50 세 이상의 경제 활동인구도 1,000 만 명을 넘어섰다. 우리나라 총 경제 활동인구 2,717 만 명 가운데 50 세 이상은 1,011만 명으로 $37 \%$ 를 점하고 있으며, 당장 2013
년에 비해서도 202만 명이 늘어 해마다 노인 인구에 대한 사회 문제가 크게 증가하고 있다. 늘어나는 노인 인구에 대한 노인복 지정책이 다양하게 요구되고 있고 이러한 요구는 2012년에 비 해 2014년에는 가족보다는 본인 스스로 혹은 정부와 사회로부 터 지원받기를 원하는 비율이 증가하였다(Statistics Korea, 2015). 초고령 사회에는 노인 본인이 생계를 책임져야 할 본인 생계 자급형 노인 인구도 크게 늘어나게 되어 사회적 일자리뿐 만 아니라 노인들의 건강이 더욱 더 중요하게 될 것이다. 노화 로 인한 신체적·기능적 변화가 다양하게 나타나게 되어 만성질 환으로 진행하게 된다. 노인병은 질병들이 동시에 나타나는 특 성이 있으며 특히 청력장애와 시력장애는 65 세 이상의 노인에 게 나타나는 아주 흔한 만성질환이다. 감각기능의 기능적 저하 는 노인의 인지 감소를 유발하게 되어 사회활동은 물론 삶의 
질에도 심각한 영향을 끼치게 된다. 따라서 청력·시력과 관련 한 연구는 노인의 생활패턴과 관련하여 야기될 사회 문제를 해 결하는 기본 정책 수립 데이터로도 중요하게 될 것이다.

노인의 감각기관의 손실로 인한 일상생활에 미치는 영향에 대하여 World Health Organization(2001)의 International classification of functioning, disability, and health를 통하여 활동의 제한(activity limitation)과 참여의 제약(participation restriction)으로 설명할 수 있다. 노인의 청력손실로 인한 활동 의 제한이란 청력손실로 인해 의사소통에 미치는 영향은 가정 혹은 사회의 대인관계에 문제가 생기거나 소음 상황 및 전화 상황에서 대화가 힘들어 어려움을 겪는 것이라 볼 수 있다. 참 여의 제약은 불편한 상황으로 인해 사회적 관계에 부정적 영향 을 미치는 경우를 말하므로 주변인과의 상호작용을 생각해야 한다(Shin, 2013). 이러한 활동의 제한과 참여의 제약은 청능재 활과 같은 재활을 할 때 반드시 고려해야 한다. 특히 청력손실 로 인한 일상생활의 어려움은 기존에 연구를 통하여 언급되어 있으나 시력손실과 관련한 의사소통 양상에 대한 영향은 널리 알려져 있지 못하다(Hickson et al., 1999; Hickson \& Worrall, 1997). 원거리 시력손실에 따른 일상생활에서 활동의 제한과 관련이 있을지 모르나 확실하지 않다(Rubin et al., 1994). 하지 만 Worrall et al.(1993)은 기능적인 시력손실로 인한 어려움에 대하여 호주의 노인 100 명을 대상으로 조사하였다. 전화번호 부, 버스 시간표, 약품 등에 쓰인 글씨와 같은 작은 글씨를 읽는 데 대부분 어려움을 호소하였다. 또한 시력손실이 있는 경우에 는 신문 읽기, 먼 거리에서 지인의 얼굴이나 모습을 알아보는 데 어려움이 있다고 하였다(Rubin et al., 1994). 얼굴 표정과 의 사소통에 있어 다른 언어표현과 관련한 중요한 단서들에 대한 인지가 시력손실이 있을 경우 줄어들 수 있어 노인의 의사소통 의 어려움에 대해서 청력과 시력손실을 모두 고려하여 노인이 현재 경험하는 문제에 맞춰 적합하고 특별한 재활프로그램을 계획해야 한다(Cruice et al., 2005; Hickson et al., 1999). 65세 이상 노인의 노화로 인한 모든 감각적 수용 기능의 저하인 청 력과 시력손실은 몸 전체 인지 기능의 감소를 유발하게 되어 삶의 질을 포함한 노인의 전반적인 사회활동 영역에 다양한 영 향을 미친다(Lee \& Wilson, 2000). 대개 개인이 한 가지의 감 각에 문제가 있는 경우에는 보상적으로 다른 감각기관이 발달 하여 다른 감각기관에 의존하게 되는 데 반해 청력 및 시력손실 은 여러 가지 감각장애가 복합되어 있어서 다른 감각의 보상이 불가능하여 어려움을 더 크게 경험하기도 하고, 청력과 시력의 두 감각기관의 손실로 인한 기능적·심리사회적 영향은 하나의 감각기관의 손실에 의한 영향보다 더욱 다양한 조합과 정도로 나타난다(Smith et al., 2008; Song, 1992). 또한 노인의 청력과 시력손실은 인지뿐 아니라 우울과 삶의 질을 포함한 전반적인
사회적 영역에도 부정적인 영향을 미치게 된다(Shin et al., 2014; Hwang et al., 2013). 이러한 청력과 시력의 두 감각기관 에 문제는 미국의 경우 70 세 이상의 노인의 약 $21 \%$ 에서 경험하 고 있고, 스웨덴의 경우는 연령대가 증가할수록 두 감각기관의 손실이 함께 나타나는 비율이 증가한 것으로 나타났다(Berry et al., 2004; Bergman \& Rosenhall, 2001). 우리나라 역시 65세 이상의 노인 50명을 대상으로 두 감각기관의 손실이 있는 경우 는 약 $66 \%$ 로 절반 이상으로 청력과 시력손실은 서로 높지는 않 지만 상관성을 보인다고 하였다(Shin et al., 2014).

따라서 본 연구를 통하여 65세 이상의 노인을 대상으로 실 제 청력검사와 시력검사를 통한 청력손실과 시력손실의 분포 를 연령별로 살피고, 간단한 설문조사를 통해 본인이 청력 및 시력으로 인하여 일상생활에서 겪는 어려움을 객관적 검사 결 과를 바탕으로 청력손실의 정도와 시력손실의 정도에 따라 비 교해보고자 하였다.

\section{MATERIALS AND METHODS}

\section{연구대상}

2015년 8 9월에 걸쳐 $\bigcirc$ 대학교 언어치료청각학과와 안경 광학과 임상 센터에 내원한 전남 지역에 거주하는 노인 중 청력 검사와 시력검사를 모두 시행한 50명(남: 19 명, 여: 31 명)의 결 과를 분석하였다. 모든 대상자는 동의서를 작성한 후 청력검사 와 시력검사 및 청력과 시력과 관련한 간단한 설문조사를 시행 하였다. 대상자의 연령은 $73.18 \pm 5.13$ 세였고, 60대(65 69세, 60), 70대(70 79세, 70), 80대 이상(80세 이상, 80+)으로 연령대 를 구분하였으며, 각 연령대별 인원수는 Table 1 과 같다. 현재 청력의 문제로 보청기를 착용하고 있는 노인은 50 명 중 1 명이었 고, 시력의 문제로 안경을 착용하고 있는 노인은 50 명 중 15 명 (30\%)이었다.

\section{연구방법}

\section{청력검사}

간단한 배경정보 조사를 통하여 현재 이과적으로 문제가 없 고 이경검사와 고막운동도 검사를 통하여 외이나 중이에 문제

Table 1. Distribution of subjects by age and gender

\begin{tabular}{lccc}
\hline \multirow{2}{*}{ Age } & \multicolumn{2}{c}{ Gender } & \multirow{2}{*}{ Total, n (\%) } \\
\cline { 2 - 3 } & Males, n (\%) & Females, n (\%) & \\
\hline $60(65-69$ yrs) & $1(7.7)$ & $12(92.3)$ & $13(26.0)$ \\
$70(70-79$ yrs $)$ & $14(43.8)$ & $18(56.3)$ & $32(64.0)$ \\
$80+(>80$ yrs $)$ & $4(80.0)$ & $1(20.0)$ & $5(10.0)$ \\
Total & $19(38.0)$ & $31(62.0)$ & $50(100.0)$ \\
\hline
\end{tabular}


가 없는 노인을 대상으로 순음청력검사를 시행하였다. 순음청 력검사는 $35 \mathrm{~dB}$ A 이하의 조용한 방에서 진행되었고 $0.5,1,2,4$ $\mathrm{kHz}$ 의 주파수에서 청력역치를 주파수별로 측정하였다. Hickson \& Worrall(1997)이 제시한 조건에 따라 오른쪽과 왼쪽 중 $0.5,1,2,4 \mathrm{kHz}$ 의 주파수에서 청력이 더 좋은 쪽 귀를 기준으로 $25 \mathrm{~dB} \mathrm{HL}$ 이하는 정상(normal), 25 40 dB HL은 경도(mild)의 청력손상, $40 \mathrm{~dB} \mathrm{HL}$ 초과는 중도 이상(moderate or greater)의 청력손상으로 분류하였다(Hickson \& Worrall, 1997). 고막운동 도 검사는 Interacoustics MT 10(Middelfart, Denmark)으로 측 정하였고 순음청력검사는 Interacoustics $\mathrm{AD}$ 226으로 측정하 였다.

\section{시력검사}

원거리시력검사는 양안의 상태에서 측정하였으며 평상시 시 력에 의한 불편함을 알아보고자 한 것이므로 안경을 착용하는 노인은 안경착용 후 교정시력을 측정하였고 안경을 착용하지 않는 노인은 원거리시력을 측정하였다. 조명을 일정하게 유지하 여 측정에 영향을 미치지 않도록 하였으며 시력 측정은 투영식 시시력표(CP-100; Dongyang, Seoul, Korea)의 같은 줄 시표 중 절반 이상을 읽었을 때 해당시력으로 하였다. 원거리시력은 Johnston(1991)의 기준에 따라 소수식 시력을 $\log M A R$ 로 환산 하여 정상(normal)은 $0.15 \log \mathrm{MAR}$ 이하(약 0.7), 경도(mild)의 시력손실은 0.16 0.55 $\log \mathrm{MAR}$ (약 0.7과 0.3 사이), 중등도 이 상(moderate or greater)의 시력손실은 $0.56 \log \mathrm{MAR}$ 이상(약 0.3 보다 나쁨)으로 분류하였다. 굴절이상도는 자동굴절검사기 (RK-F1; Canon, Tokyo, Japan)를 이용하여 측정하였다. 양안 의 굴절도수 중 굴절력이 정시에 가까운 도수를 평가에 활용하 였다. 최적구면굴절력이 $-0.50 \mathrm{D}$ 이상에서 $+1.00 \mathrm{D}$ 이하를 정 상(normal), $-0.75 \mathrm{D}$ 이상에서 $-3.00 \mathrm{D}$ 이하를 경도 근시(mild myopia), $-3.25 \mathrm{D}$ 이상을 중등도 이상 근시(moderate or greater myopia), $+1.00 \mathrm{D}$ 이상을 경도 원시(mild hyperopia)로 분류하 였다.

\section{청력 및 시력 자기보고서}

Hickson et al.(1999)과 Hannula et al.(2011)의 연구에서 사 용한 간단한 설문과 미국청각학회(American Academy of $\mathrm{Au}-$ diology)에서 제공하는 hearing health quick test에 근거하여 해석 후 우리나라의 상황에 맞도록 변형하여 현재 본인이 겪고 있는 청력의 상태와 현재 본인이 겪고 있는 시력 상태와 관련 한 문항을 제작하였다(Appendix). 청력과 시력으로 인해 평상 시 어려움을 겪고 있는지(“일상생활에서 청력 혹은 시력으로 인하여 불편함을 느끼십니까?”), 청력과 관련한 8 문항과 시력 과 관련한 7문항으로 구성하였고 일상생활에서 청력과 시력의
영향에 대한 평가를 위한 질문으로 구성된다. 모든 문항의 선 지는 “예, 아니오, 때때로”로 제시하여 답을 할 수 있도록 하였 다. 청력이나 시력에 어려움을 겪고 있는지, 청력과 시력이 좋지 않아 불편한 점, 청력과 시력으로 인한 사회 활동의 영향 등을 포함하여, 청력의 문제 1 7번과 시력의 문제 1 6번은 일상생활 에서 느끼는 불편함과 관련한 활동의 제한과 관련한 문제, 청 력의 문제 8번과 시력의 문제 7번은 저하된 청력과 시력으로 인 한 사회활동에 대한 참여의 제약과 관련한 문제로 구성되었다.

\section{자료처리}

전체(50명), 60(13명), 70(32명), 80+(5명)의 청력손실과 원거 리시력 및 굴절이상도를 기술통계 분석하고 나이, 성별에 따라 비교하였다. 청력손실의 나이대에 따른 차이는 등분산 가정 검 정 결과 등분산을 충족하지 못하여 비모수통계인 KruskalWallis 검정을 실시하고 Bonfferoni 사후검정을 유의수준 0.05 미만에서 살펴보았다. 시력과 관련한 나이 대에 따른 차이는 일 원분산분석(one-way ANOVA)를 통하여 유의수준 0.05 미만 에서 분석하였다. 청력손실과 시력손실의 성별에 따른 차이는 등분산 가정 검정 결과 등분산을 충족하여 두 독립표본 $t$ 검정 (two-independent samples $t$ test)을 유의수준 0.05 미만에서 실시하였다. 나이대, 성별, 청력손실과 원거리시력 및 굴절이상 도의 관계를 유의수준 0.01 과 0.05 미만에서 Spearman 상관분 석을 실시하여 알아보았다.

\section{RESULTS}

\section{객관적 검사}

\section{청력검사}

전체 50 명의 역치는 $0.5,1,2,4 \mathrm{kHz}$ 에서 오른쪽은 $38.30 \pm$ $10.58,35.20 \pm 12.45,35.30 \pm 15.27,45.40 \pm 19.30 \mathrm{~dB}$ HL, 왼쪽은 $41.10 \pm 14.61,35.70 \pm 16.19,36.30 \pm 16.87,43.70 \pm$ $20.89 \mathrm{~dB}$ HL로 나타나 전체적으로 오른쪽에 비해 왼쪽의 역 치가 더 나쁜 것으로 나타났다. 연령별로 $60,70,80+$ 에 따라 오른쪽과 왼쪽 모두 연령대가 증가함에 따라 역치가 증가하는 것으로 관찰되었다(Figure 1). 50명의 양쪽 귀 중 청력이 더 좋 은 쪽 귀의 $0.5,1,2,4 \mathrm{kHz}$ 의 사분법 역치는 $35.23 \pm 12.03 \mathrm{~dB}$ $\mathrm{HL}$ 이었고, $60,70,80+$ 에 따라 $27.88 \pm 6.80,36.88 \pm 12.12$, $43.75 \pm 14.50 \mathrm{~dB} \mathrm{HL}$ 로 연령대가 증가함에 따라 사분법 역치 도 증가하였다.

$0.5,1,2,4 \mathrm{kHz}$ 에서 청력이 더 좋은 쪽 귀의 사분법 평균 역 치는 연령대에 따라 등분산을 충족하지 못하였고 차이가 있는 것으로 나타났다 $(p=0.02)$. 이는 사후분석 Bonfferoni를 통해 


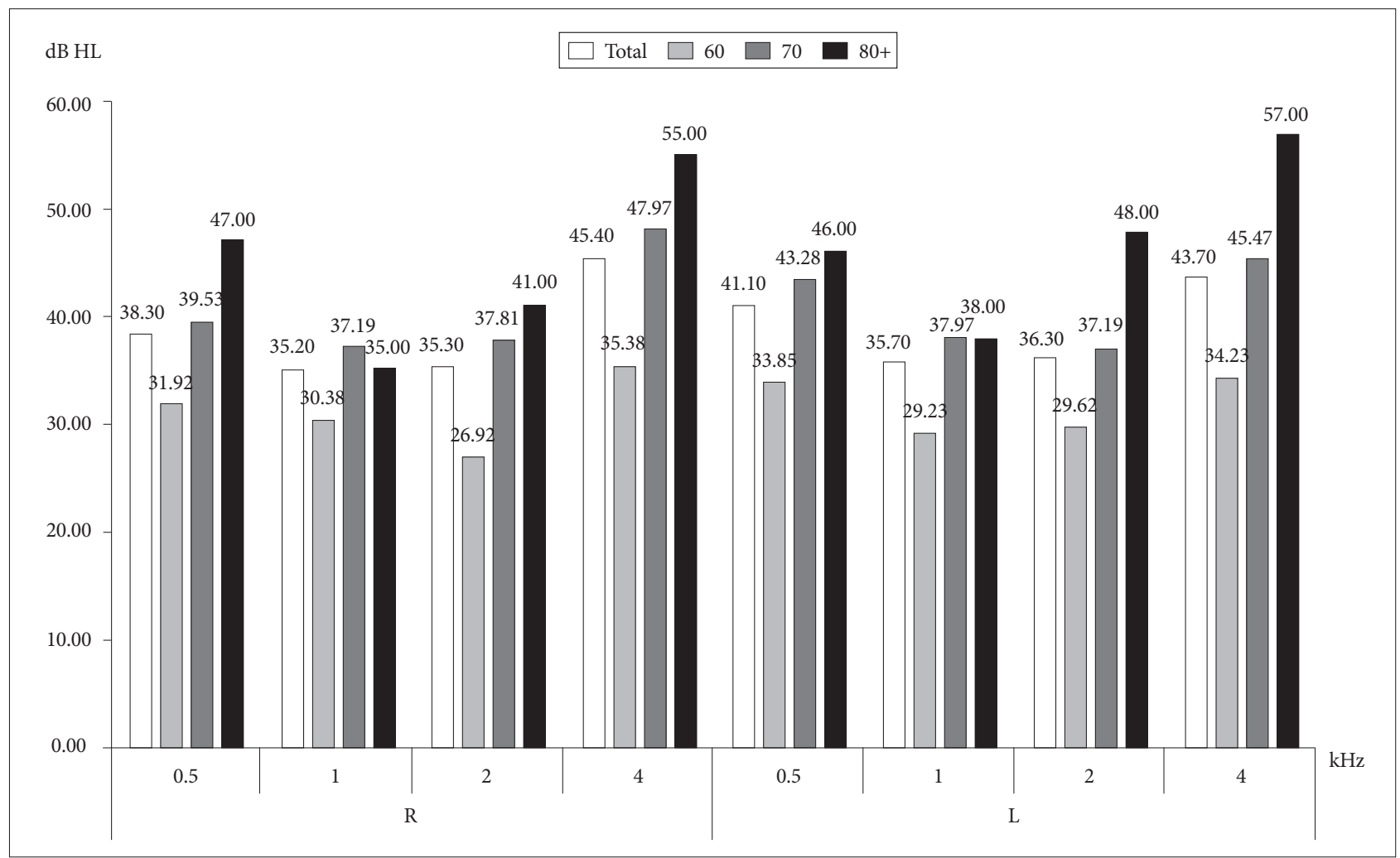

Figure 1. Thresholds of each frequency by age.

Table 2. Distribution of males and females in each age group with normal hearing, mild hearing loss, and moderate or greater hearing loss [n (\%)]

\begin{tabular}{|c|c|c|c|c|c|c|}
\hline & \multicolumn{3}{|c|}{ Males } & \multicolumn{3}{|c|}{ Females } \\
\hline & Normal & Mild & Moderate or greater & Normal & Mild & Moderate or greater \\
\hline 60 & - & - & $1(100.0)$ & $6(50.0)$ & $6(50.0)$ & - \\
\hline 70 & $1(7.1)$ & $8(57.1)$ & $5(35.7)$ & $3(16.7)$ & $7(38.9)$ & $8(44.4)$ \\
\hline $80+$ & - & $2(50.0)$ & $2(50.0)$ & - & $1(100.0)$ & - \\
\hline Total & $1(5.3)$ & $10(52.6)$ & $8(42.1)$ & $10(32.3)$ & $14(45.2)$ & $7(22.6)$ \\
\hline
\end{tabular}

60 과 80+의 차이로 인한 것으로 나타났다. 또한 청력이 더 좋은 쪽 귀의 사분법 평균 역치는 성별에 따라 차이가 있었다 $(p=$ 0.01). 청력이 더 좋은 쪽 귀의 역치와 나이 사이에는 유의수준 0.01 미만에서 상관계수 0.65 로 매우 높은 상관을 보였고, 성별 과는 유의수준 0.01 미만에서 0.34로 높지는 않으나 상관이 있 는 것으로 나타났다.

남성의 경우는 총 19 명으로 경도 난청이 총 $52.6 \%$ (10명), 중도 이상의 난청이 $42.1 \%(8$ 명), 정상은 $5.3 \%(1$ 명)으로 나타났고, 여 성은 총 31명으로 경도 난청이 45.2\%(14명), 정상이 32.3\%(10 명), 중도 이상의 난청이 $22.6 \%$ (7명)의 분포를 보였다. 60 은 남 성 1 명, 여성 12 명으로 총 13 명이었고, 남성 1 명은 중도 이상의 난청을 보였으며 여성은 정상 $50 \%$, 경도난청 $50 \%$ 로 각각 6 명 씩의 분포를 보였다. 70은 총 32명으로 남성은 14명으로 경도 난청이 $57.1 \%(8$ 명), 중도 이상의 난청이 $35.7 \%$ (5명), 정상이
$7.1 \%$ (1명)으로 경도 난청이 가장 많았으며, 여성은 총 18 명으로 중도 이상의 난청이 $44.4 \%$ (8명), 경도난청이 $38.9 \%$ (7명), 정상 이 $16.7 \%$ (3명)으로 나타났다. $80+$ 의 경우는 총 5명으로 남성은 경도 난청과 중도 이상의 난청이 각각 $50 \%(2$ 명), 여성은 1 명으 로 경도 난청을 보였다(Table 2).

\section{시력손실}

대상자 전체 50명 중 백내장 수술을 받지 않은 경우는 26명 (52\%)였고, 오른쪽만 수술을 받은 경우는 3명(6\%), 왼쪽만 수 술을 받은 경우는 2명(4\%), 양쪽을 모두 수술한 경우는 19명 (38\%)이었다. 60의 13 명 중 백내장 수술을 받지 않은 경우는 9 명(69.2\%)로 다른 연령대에 비해 제일 많았고, 오른쪽만 한 경 우는 1명(7.7\%), 양쪽을 모두 수술 받은 경우는 3명(23.1\%), 왼쪽 만 수술을 받은 경우는 없었다. 70 의 32명 중 16명(50\%)은 수 
술을 받은 경험이 없었고, 오른쪽 혹은 왼쪽만 수술을 받은 경 우는 각각 2명(6.3\%), 양쪽을 모두 수술을 받은 경우는 12명 (37.5\%)이었다. 80+의 5 명 중 수술을 받지 않은 경우는 1 명 $(20 \%)$, 나머지 4명(80\%)은 양쪽을 모두 수술 받은 경험이 있었다.

소수식으로 전체 50 명의 원거리시력은 오른쪽 $0.40 \pm 0.18$, 왼쪽 $0.39 \pm 0.19$, 오른쪽과 왼쪽 시력 중 더 좋은 쪽을 기준으 로 나타난 원거리시력은 $0.49 \pm 0.16$ 으로 나타났다. 60, 70, $80+$ 으로 나이가 들수록 오른쪽과 더 좋은 쪽 시력은 좋아지는 것으로 나타났고, 왼쪽의 시력은 60 과 $80+$ 가 70 에 비해 더 좋 은 것으로 나타났다. 또한 60 을 제외하고 70 과 $80+$ 은 오른쪽 시력보다 왼쪽 시력이 더 나쁜 것으로 보였다(Figure 2).

시력이 더 좋은 쪽 눈의 연령대에 따른 원거리시력의 분포는 등분산을 충족하고 연령대에 따라 더 좋은 쪽 시력의 차이는 없는 것으로 나타났다 $[\mathrm{F}(2,47)=1.37, p=0.26]$. 더 좋은 쪽 원 거리시력은 성별에 따라 차이가 있었고 $(p=0.03)$, 성별과 더 좋 은 쪽 원거리시력 사이에는 상관계수 0.35 의 높지는 않으나 상 관이 있는 것으로 나타났다 $(p<0.5)$.

남성의 경우는 총 19 명 중 중등도 이상의 나안시력은 없었 고, $78.9 \%$ (14명)는 경도의 시력손실, $21.1 \%$ (4명)는 정상이었다. 또한 60 의 1 명은 정상, 70 의 $78.6 \%(11$ 명)는 경도의 시력손실, $21.4 \%$ (3명)는 정상, $80+$ 의 4 명 모두는 경도의 시력손실을 가지
고 있었다. 여성 31 명 중 $77.4 \%$ (24명)는 경도의 시력손실, $12.9 \%$ (4명)는 정상, 9.7\%(3명)는 중등도 이상의 시력손실을 나타냈고, 60 의 12 명 중 $75 \%$ (9명)는 경도의 시력손실, $16.7 \%$ (2명)는 중등 도 이상, $8.3 \%$ (1명)은 정상의 시력을 보였다. 70 의 18 명 중 $83.3 \%$ (15명)가 경도의 시력손실, $11.1 \%$ (2명)가 정상, $5.6 \%$ (1명)이 중 등도 이상의 시력손실을 보였고 80+인 1명은 정상의 시력을 가 지고 있었다(Table 3).

남성의 경우 정상은 19 명 중 12 명(63.2\%)이었고, 원시가 4명 (21.1\%), 근시가 3명(15.8\%)이었고, 여성의 경우 정상은 31명 중 16 명(51.6\%), 근시가 9명(29.0\%), 원시가 6명(19.4\%)이었으며 연 령에 따른 근시와 원시 분포는 Table 4 와 같다.

\section{청력과 시력의 손실}

청력과 시력이 모두 정상인 노인은 2명으로 $4 \%$, 청력은 정상 이나 시력손실이 있는 경우는 8 명 $(16 \%)$, 시력은 정상이나 청력 손실이 있는 경우는 7명(14\%)이었으며, 청력손실과 시력손실이 모두 있는 노인은 33명으로 66\%였고, 70이 23명(69.7\%), 60이 6 명(18.2\%), 80+가 4명(12.1\%)이었다.

\section{주관적 평가}

청력손실 때문에 활동의 제한을 느끼는 문항(1 7번)은 모든

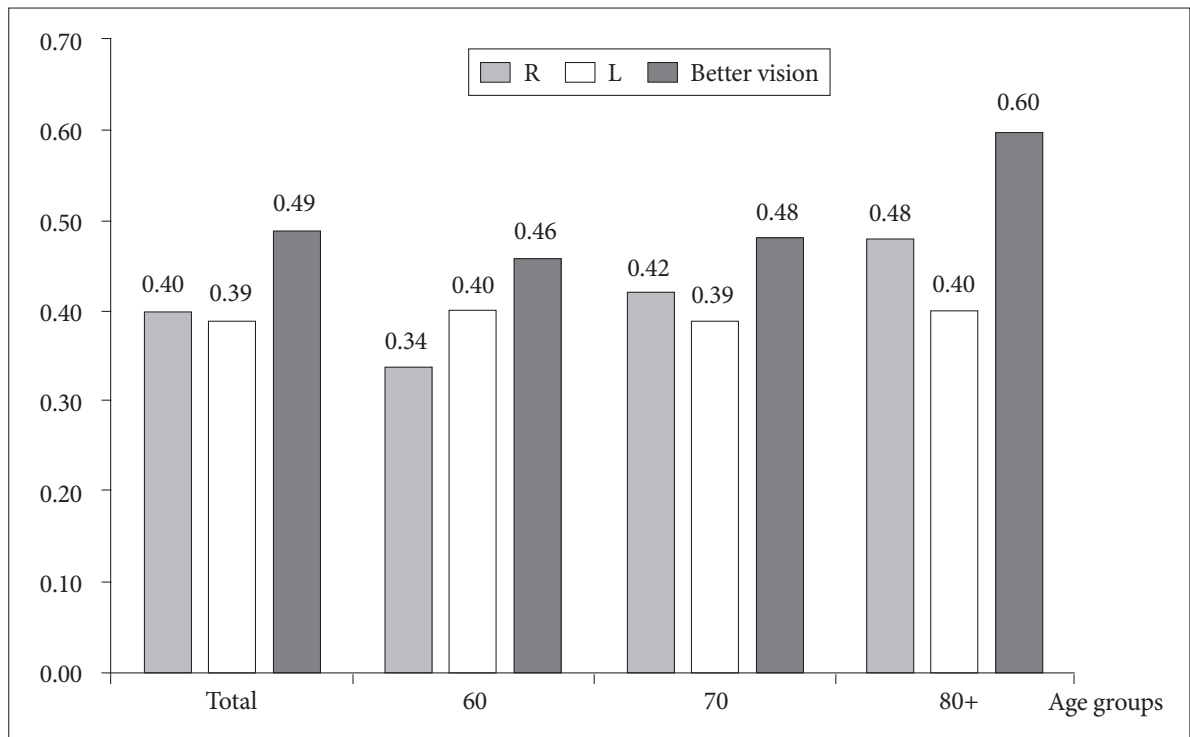

Figure 2. Distance vision by age.

Table 3. Distribution of males and females in each age group with normal distance vision, mild vision, and moderate or greater vision impairment [n (\%)]

\begin{tabular}{|c|c|c|c|c|c|c|}
\hline & \multicolumn{3}{|c|}{ Males } & \multicolumn{3}{|c|}{ Females } \\
\hline & Normal & Mild & Moderate or greater & Normal & Mild & Moderate or greater \\
\hline 60 & $1(100.0)$ & - & - & $1(8.3)$ & $9(75.0)$ & $2(16.7)$ \\
\hline 70 & $3(21.4)$ & $11(78.6)$ & - & $2(11.1)$ & $15(83.3)$ & $1(5.6)$ \\
\hline $80+$ & - & $4(100.0)$ & - & $1(100.0)$ & - & - \\
\hline Total & $4(21.1)$ & $14(78.9)$ & - & $4(12.9)$ & $24(77.4)$ & $3(9.7)$ \\
\hline
\end{tabular}


Table 4. Distribution of males and females in each age group with normal distance vision, mild vision, and moderate or greater refraction error [n (\%)]

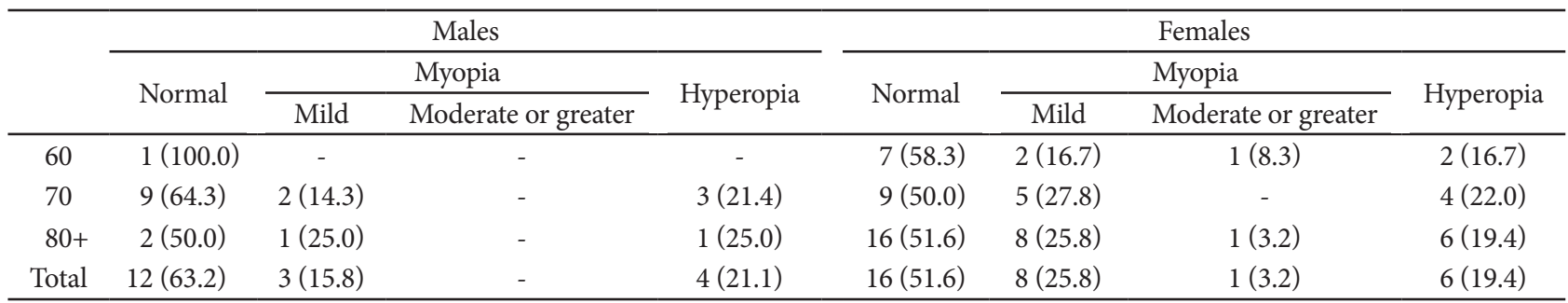

Table 5. Distribution of participants responses to hearing and vision questionnaires

\begin{tabular}{|c|c|c|c|}
\hline & \multicolumn{3}{|c|}{ Responses, n (\%) } \\
\hline & Yes & Sometimes & No \\
\hline \multicolumn{4}{|l|}{ Hearing } \\
\hline 1 I have difficulty in understanding conversation in a quiet environment. & $8(16)$ & $4(8)$ & $38(76)$ \\
\hline 2 I have difficulty with the TV and radio. & $6(12)$ & $4(8)$ & $40(80)$ \\
\hline 3 I have difficulty on conversation in a noisy restaurant or crowded room. & $11(22)$ & $6(12)$ & $33(66)$ \\
\hline 4 I have difficulty hearing on the phone. & $7(14)$ & $6(12)$ & $37(74)$ \\
\hline 5 I have difficulty hearing because mumbling or not speaking clearly. & $10(20)$ & $6(12)$ & $34(68)$ \\
\hline 6 I have difficulty in understanding a speaker at a public meeting or a religious service. & $10(20)$ & $1(2)$ & $39(78)$ \\
\hline 7 I have difficulty hearing and ask people to speak up repeat themselves. & $9(18)$ & $8(16)$ & $33(66)$ \\
\hline 8 Hearing difficulties affect my social life. & $46(92)$ & $2(4)$ & $2(4)$ \\
\hline \multicolumn{4}{|l|}{ Vision } \\
\hline 1 I have difficulty reading newspapers and books. & $24(48)$ & $20(40)$ & $6(12)$ \\
\hline 2 I have difficulty reading letters or greeting cards. & $9(18)$ & $15(30)$ & $26(52)$ \\
\hline 3 I have difficulty reading road signs and bus numbers. & $9(18)$ & $8(16)$ & $33(66)$ \\
\hline 4 I have difficulty reading instruction food package. & $9(18)$ & $16(32)$ & $25(50)$ \\
\hline 5 I have difficulty reading the numbers on telephone dials. & $16(32)$ & $7(14)$ & $27(54)$ \\
\hline 6 I have difficulty reading forms such as Medicare claim forms or bank statements. & $18(36)$ & $12(24)$ & $20(40)$ \\
\hline 7 I feel isolated because of difficulty in accessing written information. & $22(44)$ & $17(34)$ & $11(22)$ \\
\hline
\end{tabular}

문항에서 대부분의 대상자가 청력손실로 인해 활동의 제한을 느끼지 못한다는 “아니오”로 답하였고, 참여의 제약(8번)을 느 끼는 답인 “예” 혹은 “때때로”라고 답한 경우는 $96 \%$ 로 대부분 이 청력손실로 인해 참여의 제약을 느끼고 있었다. 시력손실 때문에 활동의 제한(1 6번)을 느끼는 문항에 대하여 “예" 혹은 “때때로”라고 답하여 시력손실 때문에 활동의 제한을 느끼는 것으로 나타난 문항은 1 번과 6 번 문항이었고, 4번 문항에 대해 서는 시력손실로 인해 활동의 제한을 느끼는 경우와 느끼지 못 하는 경우는 동일한 분포를 보였다. $2,3,5$ 번 문항은 시력손실 로 인해 활동의 제한을 느끼지 못한다는 “아니오”라고 답한 경 우가 시력손실로 인해 활동의 제한을 느낀다고 답한 경우보다 더 많았다. 시력손실로 인해 참여의 제약(7번)을 느끼는 답인 “예" 혹은 “때때로”라고 답한 경우는 $78 \%$ 로 시력손실로 인해 참여의 제약을 느끼는 경우도 대부분인 것으로 나타났다(Table 5).

\section{객관적 청력·시력검사와 자기보고서 비교}

객관적인 청력손실과 시력손실의 결과와 자기보고서의 청력 및 시력의 가장 일반적인 문제로 "일상생활에서 청력 혹은 시 력으로 인하여 불편함을 느끼십니까?”라는 질문에 대한 답에 대하여 실제 객관적인 검사를 통해서 살펴본 청력손실과 시력 손실의 단계, 두 가지의 감각기관의 손실로 인한 주관적인 불편 함을 Table 6과 같이 살펴보았다.

청력손실이 중도 이상일 경우 “때때로”라고 답한 비율이 가장 높았고, 경도보다는 정상일 때 어려움을 항상 느끼거나 가끔 느끼는 “예”와 “때때로”로 답한 합계의 비율이 낮아지는 것을 볼 수 있었다. 시력손실 역시 중등도 이상, 경도의 시력손실, 정 상으로 갈수록 “예”와 “때때로”라고 답한 비율이 점차 작아지 는 것으로 시력손실이 덜할수록 일상생활에 느끼는 어려움이 덜한 것으로 알 수 있었다. 청력과 시력 모두 손실이 있는 노인 의 경우를 살펴보면, 청력 혹은 시력으로 인해 평상시 어려움 을 항상 느낀다고 답한 노인의 비율이 가장 많았고 “예”와 “때 
Table 6. Distribution of participants who reported hearing or vision difficulties for each categories of impairment [n (\%)]

\begin{tabular}{|c|c|c|c|}
\hline \multirow{2}{*}{ Objective results } & \multicolumn{3}{|c|}{ Self-reported difficulty } \\
\hline & Yes & Sometimes & No \\
\hline \multicolumn{4}{|l|}{ Hearing } \\
\hline Normal $(\mathrm{n}=11)$ & $1(9.1)$ & $9(81.8)$ & $1(9.1)$ \\
\hline Mild $(\mathrm{n}=24)$ & $1(4.2)$ & $22(91.7)$ & $1(4.2)$ \\
\hline Moderate or greater $(n=15)$ & $4(26.7)$ & $10(66.7)$ & $1(6.7)$ \\
\hline \multicolumn{4}{|l|}{ Distance vision } \\
\hline Normal $(\mathrm{n}=8)$ & $1(12.5)$ & $6(75.0)$ & $1(12.5)$ \\
\hline Mild $(\mathrm{n}=39)$ & $4(10.3)$ & $33(84.6)$ & $2(5.1)$ \\
\hline Moderate or greater $(n=3)$ & $1(33.3)$ & $2(66.7)$ & - \\
\hline \multicolumn{4}{|l|}{ Dual sensory } \\
\hline Normal $(\mathrm{n}=2)$ & $1(50.0)$ & $1(50.0)$ & - \\
\hline $\begin{array}{l}\text { Hearing normal and vision } \\
\text { impairment }(\mathrm{n}=8)\end{array}$ & & $8(100.0)$ & - \\
\hline $\begin{array}{l}\text { Vision normal and hearing } \\
\text { impairment }(n=7)\end{array}$ & $1(14.3)$ & $6(85.7)$ & - \\
\hline $\begin{array}{l}\text { Dual sensory impairment } \\
(\mathrm{n}=33)\end{array}$ & $5(15.2)$ & $26(78.8)$ & $2(6.1)$ \\
\hline
\end{tabular}

때로”로 어려움을 느끼고 있다고 답한 노인은 대부분이었다. 청 력과 시력 중 하나의 감각기관에 손실이 있는 경우는 청력과 시력으로 인해 평상시 어려움을 느끼지 못한다고 답한 경우는 한 명도 없었다. 청력은 정상이나 시력손실이 있는 경우는 8명 전원이 청력 혹은 시력으로 인한 평상시 어려움을 “때때로" 있 다고 하였고 시력은 정상이나 청력손실이 있는 경우는 1 명을 제 외하고 6명이 "때때로" 어려움이 있다고 답하였다.

\section{DISCUSSIONS}

본 연구는 전남 지역에 거주하는 노인들을 상대로 청력과 시 력손실의 정도를 객관적으로 측정하고 본인이 느끼는 청력과 시력손실에 대한 영향을 주관적으로 측정해 보았다.

청력손실이나 시력손실이 한 가지만 존재하는 경우의 비율은 거의 같았으나 두 기능 모두 손실이 있는 경우는 $66 \%$ 로 매우 높은 비율을 차지하고 있으며 80대 이상은 5명으로 모집 단위 가 작아서 유의미한 통계를 보이기는 어려우나 특히 70대에서 가장 높게 나타났고 연령대별 차이가 있는 것으로 나타났다 $(p$ $<0.05)$.

본 연구의 결과 청력손실로 인하여 활동의 제한을 느끼는지 에 대하여 묻는 문항은 1 7번으로 각 문항별로 $65 \sim 55 \%$ 정도 의 분포로 일상생활에서 활동의 제한을 느끼지 못하고 있었다. $\mathrm{TV}$ 시청이나 교회 연설과 같이 스피커를 통해 듣는 경우에는 불편을 느끼지 않는다고 답한 경우는 각각 $80 \%$ 와 $78 \%$ 로 다른 항목에 비해 훨씬 높게 나왔다. 하지만 식당이나 사람이 많은 곳에서 대화를 하는 데 불편을 느끼지 않는 경우는 $66 \%$ 로 타
항목보다는 작게 나타났다. 이는 본 연구에 참여한 노인들은 거의 노인 부부나 홀로 생활하는 노인으로 특히 시골에서 살면 서 도시보다는 주위의 환경에 영향을 덜 받는 경우로 생각할 수 있다. TV 시청 시 본인들이 듣고 싶은 정도의 큰 소리크기 로 시청하는데 시골 마을 골목길에서는 대개 TV 소리나 전화 목소리가 담 밖까지 들리는 경우가 대부분이다. 이러한 생활 환 경이 청력손실에 대한 생활의 불편을 감소할 수 있는 것이라 생 각한다. 교회 등에서는 이들을 위한 동네 교회이므로 반향(reverberation)이 적고 노인의 특성을 고려한 예배 등이 이루어지 고 낮선 이들과 생활보다는 친숙한 지인들과의 활동으로 청력 손실로 인한 큰 불편을 느끼지 못할 수 있다고 생각한다. 식당 이나 사람이 많은 경우는 본인들이 원하는 정도의 신호대잡음 비(signal to noise ratio)의 조절에 제한이 있을 수 있으나 이 역시 주위 환경 영향에 민감하지 않아도 되는 식당이나 양로 원, 마을회관 등의 다중 시설을 이용하므로 생활에 불편을 덜 느끼는 것으로 사료된다. 하지만 청력손실로 인하여 사회활동 에 참여의 제약을 느끼는 경우가 $96 \%$ 로 대부분 생활에 어려 움을 느끼고 있었는 바 노인의 청력손실을 위한 프로그램이 범 국가적으로 시행되어야 할 것으로 생각한다. 주관적인 설문의 결과인 청력손실로 인한 어려운 상황에 대한 조사로 청력손실 정도를 예측하는 것은 $0.5 \sim 4 \mathrm{kHz}$ 의 역치보다는 고주파수인 4 $8 \mathrm{kHz}$ 를 통하여 예측하기 용이하다(Hannula et al., 2011). 하 지만 본 연구에서는 $4,6,8 \mathrm{kHz}$ 의 역치를 구하여 비교해 보지 못했기 때문에 본 연구에서 사용한 주관적 설문지 결과와 실제 청력 역치를 비교하지 못하였다.

시력손실로 인하여 사회활동에 활동의 제한을 느끼는 경우 는 1번과 6번 문항에서 크게 나타났는데 특히 "신문이나 책을 읽기가 어렵다"는 $88 \%$ 로 책의 활자체는 다른 읽을거리들보다 활자체가 작은 것이기 때문이라고 여겨지며 일상생활 중 비교 적 큰 활자체로 구성된 간판이나 버스 번호는 식별하는 데 받는 영향이 타 경우보다는 적게 나타났으나, 글씨 크기나 크지만 보 는 거리가 멀어 불편함이 있었던 것으로 생각한다. 글자는 크나 가까이 보아야 하는 마트에서의 상품 이름은 $50 \%$ 로 절반 정도 가 불편함을 느낀다고 답하였다. 시력손실로 인하여 사회활동 에 참여의 제약을 느낀다고 답한 경우도 $78 \%$ 에 달하여 이 역 시 사회적 문제가 아닐 수 없다.

Hickson et al.(1999)의 호주 노인 240명을 대상으로 한 객관 적인 청·시각 손실과 주관적인 참여의 제약과 활동의 제한을 비교한 연구에 따르면 본 연구 결과와 차이가 있다. 선생연구는 청력손실이 경도 난청일 경우 “항상” 불편함을 호소하는 경우 가 $45.3 \%$ 로 높았으나 본 연구에서는 “때때로" 불편함을 느끼는 경우가 $91.7 \%$ 로 다수를 차지하고 있었다. 선행연구에서는 경도 시력손실일 때에는 $51.6 \%$ 가 불편함을 느끼지 못하고 있으나 
본 연구에서는 “때때로"가 84.6\%로 높게 나타났다. 이러한 차 이는 모표본수와 문화적 생활 환경 차이에서 오는 것으로 추측 된다. 보청기 보급 정도나 돋보기 비치 환경 등 노인을 위한 생 활복지 환경과 관련하여 더욱 세밀한 연구가 이루어져야 할 것 으로 본다.

전체 대상자 50명 중 $48 \%$ 인 24명이 백내장 수술을 받은 것 으로 나타났다. 60 은 $30.8 \%$ 로 다른 연령대보다 제일 작았으며 70 은 $50 \%, 80+$ 의 경우에는 $80 \%$ 로 수술을 받은 비율이 연령이 증가할수록 높게 나타났다. $60,70,80+$ 로 나이가 들수록 원거 리 시력이 더 좋은 것으로 나타났는데 이는 백내장 수술로 인 하여 향상이 이루어졌다는 점, 원거리시력 측정 시 평상시 느 끼는 불편함을 비교하기 위하여 안경을 착용한 노인의 경우는 안경 착용 후 노인의 시력을 측정하였기 때문에 연령이 증가할 수록 원거리시력이 나빠질 것이라 예상했던 것과는 반대의 결 과를 보였다. 하지만 본 연구 결과를 통하여 볼 때 시력손실과 관련한 일상생활의 불편함을 고려할 때는 백내장 수술 여부에 대하여 반드시 염두에 두어야 할 것으로 생각한다.

노인들의 중요한 관심사이면서 걱정거리는 역시 건강을 빼 놓 을 수 없다. 청력과 시력의 감각기관에 기능적 이상이 있을 때 나타나는 사회적 영향은 하나의 기관이 이상이 있을 때보다 2 배가 아니라 그 이상이라고 보고되어 있다(Shin et al., 2014). 특 히 이상이 있는 경우 처음부터 적극적으로 병원을 방문하는 것 이 아니므로 경도의 경우는 놓치기 쉬워 병원 치료나 다른 보 조요법을 통하여 기능을 회복시키기도 매우 어렵다고 생각한 다. 청력이나 시력의 손실은 만성질환의 경우와 마찬가지로 그 원인은 여러 가지이고 이것들이 복합적으로 작용하기 때문에 특정 위험요인이나 한정된 1차 원인을 밝혀낸다는 것은 더욱 어려우므로 질병 발생 이전에 예방한다는 것도 쉽지가 않다. 건 강한 노인이라 할지라도 나이가 들어가면서 의사소통을 유지하 기 위해서는 청력과 시력을 주기적으로 확인하여 필요에 따라 청각보조장치, 시각보조장치 및 의료적 치료 등과 같은 적합한 중재를 해야 한다(Cruice et al., 2005). 지역사회 전체 주민을 상대로 체계적이면서도 효과적인 방법으로 노인의 건강을 관 찰하고 질병을 관리하는 데에 정책적 배려가 요구되고 있다. 재 활을 통해 불능의 문제를 최소화시키기 위해 치료를 통해 효과 적으로 신체 기능을 유지할 수 있도록 치료 및 훈련시키는 포 괄적인 노력 역시 병행되어야 할 것이다. 또한 본 연구의 게재문 항은 번역을 한 것으로 원본의 서술형 문항을 질문형 문항으로 의역하였기 때문에 외국의 결과와 차이를 보일 수밖에 없었을 것이라 생각하고, 문항 간의 정교한 신뢰도 분석은 추후 이루어 져야 할 것이라 본다. 하지만 우선 본 연구의 결과만 보더라도 앞으로 노인 복지정책의 방향이 청력과 시력과 관련한 건강 역 시 고려하여 이루어지는 것이 좋을 것으로 생각한다.
중심 단어 : 청력손실·시력손실·두 감각기관 저하· 객관적 평가·주관적 설문.

Acknowledgments

이 논문은 2016년도 세한대학교 교내연구비 지원에 의하여 쓰여 진 것임.

\section{REFERENCES}

American Academy of Audiology. Hearing health quick test. Retrieved from http://www.howsyourhearing.org/FSQuickTest.pdf.

Bergman, B. \& Rosenhall, U. (2001). Vision and hearing in old age. Scandinavian Audiology, 30(4), 255-263.

Berry, P., Mascia, J., \& Steinman, B. A. (2004). Vision and hearing loss in older adults: "double trouble". Care Management Journals, 5(1), 35-40.

Cruice, M., Worrall, L., \& Hickson, L. (2005). Personal factors, communication and vision predict social participation in older adults. Advances in Speech-Language Pathology, 7(4), 220-232.

Hannula, S., Bloigu, R., Majamaa, K., Sorri, M., \& Maki-Torkko, E. (2011). Self-reported hearing problems among older adults: Prevalence and comparison to measured hearing impairment. Journal of the American Academy of Audiology, 22(8), 550-559.

Hickson, L., Lind, C., Worrall, L., Yiu, E., Barnett, H., \& Lovie-Kitchin, J. (1999). Hearing and vision in healthy older Australians: objective and self-report measures. Advances in Speech-Language Pathology, 1(2), 95105.

Hickson, L. \& Worrall, L. (1997). Hearing impairment, disability, and handicap in older people. Critical Reviews in Physical and Rehabilitation Medicine, $9(3 \&$ 4), 219-243.

Hwang, J. H., Shin, E. Y., \& Kim, J. S. (2013). A study on hearing self-status and aural rehabilitation program needs of the elderly who attend geriatric welfare. Audiology, 9(2), 175-189.

Johnston, A. W. (1991). Making sense of the M, N, and log MAR systems of specifying visual acuity. In B. P. Rosenthal \& R. G. Cole. Problems in optometry: A structured approach to low vision care (pp. 394-407). Philadelphia: J. B. Lippincott.

Lee, B. L. \& Wilson, M. R. (2000). Health-related quality of life in patients with cataract and glaucoma. Journal of Glaucoma, 9(1), 87-94.

Rubin, G. S., Roche, K. B., Prasada-Rao, P., \& Fried, L. P. (1994). Visual impairment and disability in older adults. Optometry and Vision Science, 71(12), 750-760.

Shin, E. Y. (2013). The standards quality of life scales for hearing handicap of the elderly. Audiology, 9(2), 165-174.

Shin, E. Y., Cho, S. J., \& Joo, S. H. (2014). The characteristics of vision and hearing for elderly people in Jeallanam-do. The Korean Journal of $\mathrm{Vi}$ sion Science, 16(4), 493-502.

Smith, S. L., Bennett, L. W., \& Wilson, R. H. (2008). Prevalence and characteristics of dual sensory impairment (hearing and vision) in an veteran population. Journal of Rehabilitation Research and Development, 45(4), 597-609.

Song, M. S. (1992). Effects of the sensory impairment on functioning levels of the elderly. The Journal of Korean Academic of Nursing, 23(4), 678-693.

Statistics Korea. (2015). 2015 elderly statistics. Statistics Korea. Retrieved from http://kostat.go.kr/portal/korea/kor_nw/2/1/index.board?bmode= read\&aSeq $=348565$.

World Health Organization. (2001). International Classification of Functioning, Disability and Health: ICF. Geneva, Switzerland: World Health Organization.

Worrall, L., Hickson, L., Barnett, H., \& Lovie-Kitchin, J. (1993). The performance of older people on everyday visual tasks. Clinical and Experimental Optometry, 76(4), 127-135. 
Hearing and vision questionnaires

반응

항상 때때로 아니오

Hearing

1 조용한 상황에서 대화를 이해하기 힘든가요?

2 TV나 라디오, 혹은 영화를 볼 때 잘 들리지 않아 어려움을 경험한 적이 있으십니까?

3 식당이나 사람이 많은 곳과 같은 시끄러운 상황에서 대화를 하기 힘든가요?

4 전화 상 목소리를 이해하기 힘듭니까?

5 다른 사람들이 말할 때 웅얼거리거나 분명하게 들리지 않을 때가 있습니까?

6 연설이나 교회와 같은 곳에서 스피커를 통한 목소리가 이해하기 어려울 때가 있습니까?

7 다른 사람들에게 목소리를 키워 달라고 하거나 반복해서 말해달라고 할 때가 있습니까?

8 잘 들리지 않는 것이 사회생활에 영향을 미친다고 생각하십니까?

Vision

1 신문이나 책을 읽기가 어려운가요?

2 청첩장이나 부고장 읽기가 어려운가요?

3 거리의 간판, 버스번호를 알아보기가 어려운가요?

4 마트에서 상품이름을 알아보기가 어려운가요?

5 휴대폰의 숫자를 읽기가 어려워 전화를 제대로 걸지 못하나요?

6 은행이나 군청, 보건소에서 문서 작성 시 잘 보이지 않아 서류 작성이 어려운가요?

7 눈이 침침해져 뉴스나 신문을 제대로 읽지 못해 세상소식에 뒤떨어져 있다고 생각하십니까? 